\title{
16. SEISMIC VELOCITIES, DENSITIES, AND ELASTIC CONSTANTS OF BASALTS FROM DSDP LEG 35
}

\author{
Nikolas I. Christensen, Department of Geological Sciences and \\ Graduate Program in Geophysics, University of Washington, Seattle, Washington
}

\section{INTRODUCTION}

Velocity measurements of elastic waves in DSDP samples are important for interpreting marine seismic data. In this paper compressional wave velocities $\left(\mathrm{V}_{\mathrm{p}}\right)$, shear wave velocities $\left(\mathrm{V}_{\mathrm{s}}\right)$, and densities are presented for four samples of basalt obtained from Sites 322 and 323. The velocities were measured in the laboratory under conditions of hydrostatic confining pressure to 6.0 kbar using a pulse transmission technique similar to that described by Birch (1960). The samples were cut in the form of right circular cylinders $1.3 \mathrm{~cm}$ in diameter and 3 to $4 \mathrm{~cm}$ in length. Since it is well known that at in situ pressures common for ocean floor basalts water saturation significantly increases basalt compressional wave velocities (e.g., Nur and Simmons, 1969; Christensen, 1970), velocities were measured under saturated conditions. Pore pressures were maintained at values lower than external pressures by placing a 100 mesh screen between the samples and copper jackets.

The basalts selected for the measurements from Site 322 contain plagioclase microphenocrysts in a finegrained variolitic groundmass. Both samples are slightly altered with relatively low bulk densities. In addition to alteration, the low density $(2.55 \mathrm{~g} / \mathrm{cc})$ of Sample 322-13$2,56-62 \mathrm{~cm}$ is due in part to the presence of open vesicles. Sample 322-12-1 (piece 7) with a bulk density of $2.73 \mathrm{~g} / \mathrm{cc}$, on the other hand, contains montmorillonite amygdules.

The two samples investigated from Site 323 are similar in mineralogy and texture. Both have intergranular-intersertal textures and contain significant alteration products. Calcite veins were avoided in the preparation of samples for the velocity measurements.

\section{VELOCITIES AND ELASTIC MODULI}

The velocities and bulk densities of the samples are given in Table 1. For conciseness most of the tabulated data are smoothed values given over 0.2-kbar intervals for the first kilobar increase in pressure. One example of the original data is given in Figure 1. For this sample compressional wave velocities measured during decreasing pressure were found to be slightly lower than values obtained while increasing pressure. This is opposite from what has commonly been observed in dry rocks (Birch, 1960).

Values of the ratio of compressional to shear wave velocity $\left(\mathrm{V}_{\mathrm{p}} / \mathrm{V}_{\mathrm{s}}\right)$, Poisson's ratio $(\sigma)$, the seismic parameter $(\phi)$, the bulk modulus $(\mathrm{K})$, the compressibility $(\beta)$, the shear modulus $(\mu)$, Young's modulus (E), and Lamé's constant $(\lambda)$ calculated from measured densities and velocities are given in Table 2 at selected pressures for each sample. The equations relating these constants to velocities and density are given by Birch (1961).

\section{DISCUSSION}

Previous investigations of elastic wave velocities in DSDP basalts (e.g., Christensen and Salisbury, 1972, 1973) have shown that both $V_{p}$ and $V_{s}$ show wide ranges ( 3.5 to $6.5 \mathrm{~km} / \mathrm{sec}$ for $\mathrm{V}_{\mathrm{p}}$ and 1.7 to 3.7 for $\mathrm{V}_{\mathrm{s}}$ at 0.5 kbar) which are linearly related to density and sea-floor age. Basalts with low velocities and densities are usually old and have been highly weathered due to prolonged exposure to seawater. Combined data from 18 Pacific and Atlantic sites give rates of decreasing velocity of -1.89 and $-1.35 \mathrm{~km} / \mathrm{sec}$ per $100 \mathrm{~m} . \mathrm{y}$. for $\mathrm{V}_{\mathrm{p}}$ and $\mathrm{V}_{\mathrm{s}}$, respectively. Likewise the least-squares solution for 52 density measurements of DSDP basalts gives a rate of decrease in density of $16 \%$ per 100 m.y. (Salisbury and Christensen, 1973).

The velocity and density measurements of Table 1 are compared in Figure 2 with DSDP basalt data summarized by Christensen and Salisbury (1975). It is apparent that the new data are in agreement with previously determined velocity-density relations (Figure 2). Furthermore the velocities and densities of Leg 35 basalts are significantly lower than many unaltered relatively young DSDP basalts, which suggests ages greater than $40 \mathrm{~m} . \mathrm{y}$. for the samples from both sites.

\section{ACKNOWLEDGMENTS}

Technical assistance in the maintenance and operation of the high-pressure system was provided by Robert McConaghy and Michael Brown. This investigation was supported by the Office of Naval Research Contract N-00014-67-A-0103-0014 and National Science Foundation Grant GA-36138.

\section{REFERENCES}

Birch, F., 1960. The velocity of compressional waves in rocks to 10 kilobars, 1: J. Geophys. Res., v. 65, p. 1083. 1961. The velocity of compressional waves in rocks to 10 kilobars, 2: J. Geophys. Res., v. 66, p. 2199.

Christensen, N.I., 1970. Compressional wave velocities in basalts from the Juan de Fuca Ridge: J. Geophys. Res., v. 75, p. 2773.

Christensen, N.I. and Salisbury, M.H., 1972. Sea floor spreading, progressive alteration of Layer 2 basalts and associated changes in seismic velocities: Earth Planet. Sci. Lett., v. 15., p. 367.

1973. Velocities, elastic moduli and weathering-age relations for Pacific Layer 2 basalts: Earth Planet. Sci. Lett., v. 19, p. 461.

1975. Structure and constitution of the lower oceanic crust: Rev. Geophys. Space Phys., v. 13, p. 57.

Nur, A. and Simmons, G., 1969. The effect of saturation of velocity in low porosity rocks: Earth Planet. Sci. Lett., v. 7, p. 183.

Salisbury, M.H. and Christensen, N.I., 1973. Progressive weathering of submarine basalt with age: further evidence of sea-floor spreading: Geology, v. 1, p. 63. 
TABLE 1

Compressional (P) and Shear (S) Wave Velocities

\begin{tabular}{lc|ccccccccc}
\hline \multirow{2}{*}{$\begin{array}{c}\text { Sample } \\
\text { (Interval } \\
\text { in cm) }\end{array}$} & $\begin{array}{c}\text { Bulk } \\
\text { Density }\end{array}$ & \multicolumn{10}{c}{ Velocity $(\mathrm{km} / \mathrm{sec})$ at Varying Pressures (kbar) } \\
\cline { 3 - 11 } & Mode & 0.2 & 0.4 & 0.6 & 0.8 & 1.0 & 2.0 & 4.0 & 6.0 \\
\hline $322-12-1$ & 2.730 & $\mathrm{P}$ & 5.50 & 5.52 & 5.53 & 5.54 & 5.56 & 5.61 & 5.69 & 5.74 \\
(piece 7) & 2.730 & $\mathrm{~S}$ & 2.98 & 2.99 & 3.00 & 3.01 & 3.02 & 3.05 & 3.07 & 3.09 \\
$322-13-2$, & 2.553 & $\mathrm{P}$ & 4.87 & 4.89 & 4.91 & 4.93 & 4.94 & 5.01 & 5.09 & 5.14 \\
$56-62$ & 2.553 & $\mathrm{~S}$ & 2.58 & 2.60 & 2.61 & 2.63 & 2.64 & 2.69 & 2.74 & 2.76 \\
$323-18-6$, & 2.727 & $\mathrm{P}$ & 5.44 & 5.45 & 5.47 & 5.48 & 5.49 & 5.55 & 5.62 & 5.67 \\
$110-120$ & 2.727 & $\mathrm{~S}$ & 2.82 & 2.84 & 2.86 & 2.87 & 2.88 & 2.91 & 2.95 & 2.96 \\
$323-20, \mathrm{CC}$ & 2.723 & $\mathrm{P}$ & 5.30 & 5.31 & 5.33 & 5.34 & 5.35 & 5.41 & 5.48 & 5.54 \\
and 104-114 & 2.723 & $\mathrm{~S}$ & 2.88 & 2.90 & 2.91 & 2.92 & 2.92 & 2.95 & 2.97 & 2.98 \\
\hline
\end{tabular}

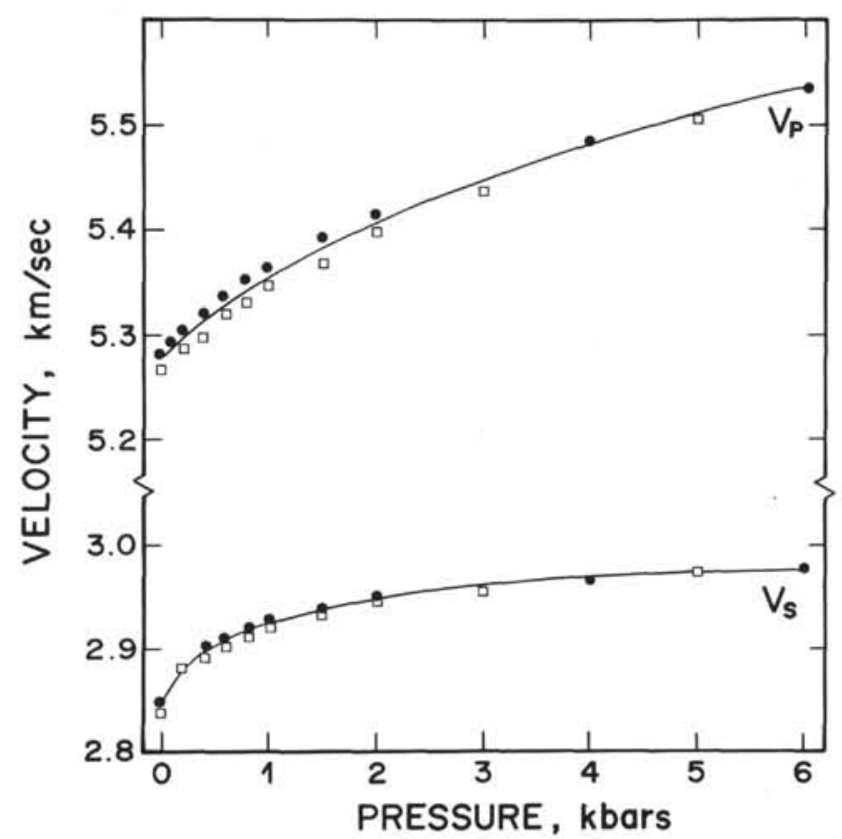

Figure 1. Compressional and shear velocities for basalt Sample 323-20 CC, 104-114 cm. Dots indicate measurements with increasing pressure and squares are measurements with decreasing pressure. 
TABLE 2

Elastic Constants

\begin{tabular}{lccccccccc}
\hline $\begin{array}{c}\text { Sample } \\
\text { (Interval } \\
\text { in cm) }\end{array}$ & $\begin{array}{c}\text { Pressure } \\
(\mathrm{kb})\end{array}$ & $\mathrm{V}_{\mathrm{p}} / \mathrm{V}_{\mathrm{s}}$ & $\sigma$ & $\begin{array}{c}\phi \\
\left(\mathrm{km} \mathrm{s}^{-1}\right)^{2}\end{array}$ & $\begin{array}{c}\mathrm{K} \\
(\mathrm{Mb})\end{array}$ & $\begin{array}{c}\beta \\
\left(\mathrm{Mb}^{-1}\right)\end{array}$ & $\begin{array}{c}\mu \\
(\mathrm{Mb})\end{array}$ & $\begin{array}{c}\mathrm{E} \\
(\mathrm{Mb})\end{array}$ & $\begin{array}{c}\lambda \\
(\mathrm{Mb})\end{array}$ \\
\hline $322-12-1$ & 0.4 & 1.84 & 0.29 & 18.5 & 0.51 & 1.98 & 0.24 & 0.63 & 0.34 \\
(piece 7) & 1.0 & 1.84 & 0.29 & 18.7 & 0.51 & 1.95 & 0.25 & 0.64 & 0.35 \\
& 2.0 & 1.84 & 0.29 & 19.1 & 0.52 & 1.92 & 0.25 & 0.65 & 0.35 \\
& 6.0 & 1.86 & 0.30 & 20.1 & 0.56 & 1.80 & 0.26 & 0.68 & 0.38 \\
$322-13-2$, & 0.4 & 1.88 & 0.30 & 14.9 & 0.38 & 2.62 & 0.17 & 0.45 & 0.27 \\
$56-62$ & 1.0 & 1.87 & 0.30 & 15.1 & 0.39 & 2.59 & 0.18 & 0.46 & 0.27 \\
& 2.0 & 1.86 & 0.30 & 15.4 & 0.39 & 2.53 & 0.19 & 0.48 & 0.27 \\
$323-18-6$, & 6.0 & 186 & 0.30 & 16.1 & 0.42 & 2.39 & 0.20 & 0.51 & 0.29 \\
$110-120$ & 0.4 & 1.92 & 0.31 & 18.9 & 0.52 & 1.93 & 0.22 & 0.58 & 0.37 \\
& 1.0 & 1.91 & 0.31 & 19.1 & 0.52 & 1.91 & 0.23 & 0.59 & 0.37 \\
$323-20, \mathrm{CC}$ & 2.0 & 1.91 & 0.31 & 19.4 & 0.53 & 1.88 & 0.23 & 0.61 & 0.38 \\
and 104-114 & 6.0 & 1.91 & 0.31 & 20.3 & 0.56 & 1.79 & 0.24 & 6.33 & 0.40 \\
& 1.0 & 1.83 & 0.29 & 17.0 & 0.46 & 2.16 & 0.23 & 0.59 & 0.31 \\
& 2.0 & 1.83 & 0.29 & 17.2 & 0.47 & 2.13 & 0.23 & 0.60 & 0.31 \\
& 6.0 & 1.86 & 0.29 & 17.6 & 0.48 & 2.07 & 0.24 & 0.61 & 0.32 \\
& & 0.30 & 18.7 & 0.51 & 1.94 & 0.24 & 0.63 & 0.35 \\
\hline
\end{tabular}

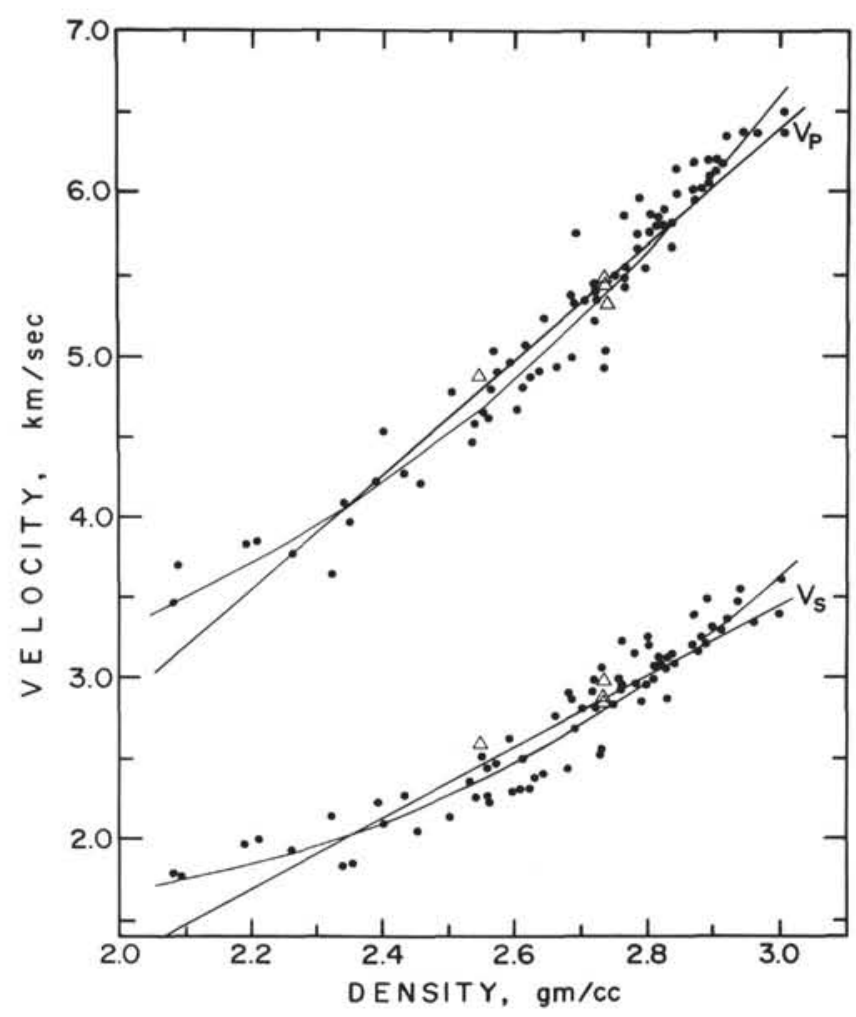

Figure 2. Velocity-density data at 0.5 kbar for previously studied DSDP basalts (dots) and Leg 35 basalts (triangles). 